薬剤師を真の“ゲートキーパー”とするために 〜薬剤師が潜在的な精神科疾患や過量投与, 自殺をピックアップできるようになるためにはどうすることが必要か〜

\author{
大澤匡弘, ${ }^{*, a} 川$ 村 和 美 ${ }^{b, \dagger}$
}

\title{
Pharmacist as a Real "Gatekeeper" for the Prevention of Suicide, Overdosage and Depression: What Should We Need?
}

\author{
Masahiro Ohsawa ${ }^{*, a}$ and Kazumi Kawamura ${ }^{b, \uparrow}$ \\ ${ }^{a}$ Laboratory of CNS Pharmacology, Graduate School of Pharmaceutical Sciences, Nagoya City University; \\ 3-1 Tanabe-dori, Mizuho-ku, Nagoya 467-8603, Japan: and ${ }^{b}$ Sugi Medical Co., Ltd.; \\ 2-6-1 Kaji-cho, Chiyoda-ku, Tokyo 101-0044, Japan.
}

現在の日本では, 自殺者が年間 3 万人の大台から 減ることがない。近年の自殺者の傾向は，若年者の みならず中高年者にも広くみられることが挙げられ る。これは，社会構造の変化や長引く不況などによ り，日本人の多くが多くのストレスを抱え，精神的 な失調をきたしていることが主要な原因であると言 われている。この自殺者を減らすため，2011年 秋, 厚生労働省の自殺・うつ病等対策プロジェクト チームが結成された。このプロジェクトチームから 提出された『過量服薬への取組』の「解決に向けて 実施する取組」に“薬剤師の活用”が挙げられた. この取組には「薬剤師が過量服薬のリスクの高い患 者のゲートキーパー」と位置づけられている，以 来，薬剂師向けのゲートキーパー研修会が各地で開 催され始めており，全国の薬剤師が“ゲートキー パー”として幅広く活躍するための知識や方法の充 実と提供が強く望まれるようになった。

自殺の背景には，様々な要因が存在するが，その 中でもうつ病や薬物依存といつた精神疾患がある.

薬剂師は, 病気の認識がない人や薬物の乱用が疑わ れる人，処方薬依存に陥つている人など，問題を抱 えるであろう多くの人びとと接することができる立

$a$ 名古屋市立大学大学院薬学研究科中枢神経機能薬理学 分野 (T 467-8603 名古屋市瑞穂区田辺通 3-1), ${ }^{b}$ 人ギ メディカル株式会社教育事業部（テ101-0044 東京都千 代田区鍛冶町 2-6-1)

現所属: ‘シップヘルスケアファーマシー東日本株式会 社教育研修部（干981-3133 仙台市泉区泉中央 3-29-7)

*e-mail: ohsawa@phar.nagoya-cu.ac.jp

日本薬学会第 132 年会シンポジウム S37 序文
場にある，つまり，精神疾患や薬物依存などの正し い知識を得ることで，問題があると思われる地域住 民を医師へとつなげることが可能となり，病態の悪 化や自殺など深刻な問題に至る前に患者を救うこと ができるかもしれない，主な自殺の原因が精神疾患 や薬物乱用にあるとすれば，薬剤師のこのようなス キルを上げることにより，自殺のゲートキーパーと しての役割を果たすことが可能になると言える.

本シンポジウムでは, 薬剤師が増加を続ける精神 疾患を原因とする自殺の歯止めとなるゲートキー パーとなるためには，どのような知識や技能が必要 であるかについて, 精神疾患や薬物依存の領域にお いて第一線でご活躍されている先生方にお集まり頂 き, 議論を行った.『過量服薬への取組』をご提案 された国立精神・神経医療研究センター精神保健研 究所の松本俊彦先生からは, わが国の自殺の現状や 自殺の背景知識と, 自殺予防者講習会を牽引されて いるお立場から薬剤師が習得しなくてはならない知 識や技能，そして薬剤師活躍の可能性についてお話 を頂いた，続いて，同センター所属の薬物依存の疫 学研究を専門とする嶋根卓也先生からは, 薬物依存 の現状と医薬品の乱用，そして薬剤師のお立場から 薬剂師が取り組めることなどについて具体的にお話 頂いた。 また, 米国内科学会総会で 2002 年より行 われている PIPC (Psychiatry in Primary Care : 内 科医が内科診療の現場における精神科疾患の診かた ができるようになるための教育訓練システム）と呼 ばれるプライマリ・ケア医を対象に精神疾患を診断 する方法を日本に導入した井出広幸先生からは，プ 
ライマリ・ケア医として薬剤師に望む技能や医師と の関係性の構築などについてお話頂いた．最後に, 現場の薬剤師教育に取り組んでおられる川村和美先 生からは，自殺のゲートキーパーとしての薬剤師育 成に係わってきたご経験から，薬剤師に対する教育 や人文社会科学的視点から精神疾患並びに薬物依存 症の患者を見極めるための方法論などについてお話 を頂いた。

本誌上シンポジウムでは，井出先生を除くお三方
の先生から，シンポジウムでお話頂いた内容に新し い内容を加えて頂き，ご執筆を頂いた．本誌上シン ポジウムからでも，薬剤師がゲートキーパーとなる ために必要なエッセンスが網羅できるようなすばら しい内容になっている。 今後, 本シンポジウムの テーマである薬剤師が自殺のゲートキーパーとして 活躍し，日本国国民の恒久の福祉の向上のために活 躍することを期待している。 